\title{
INTERNALISASI AKUNTANSI MANAJEMEN PERSPEKTIF BALANCE SCORECARD DALAM PENGUKURAN KINERJA PERGURUAN TINGGI
}

\author{
Helmy Adam \\ Jurusan Akuntansi Universitas Brawijaya Malang \\ Jl. MT. Haryono 165 Malang 65145 \\ Telp. 0341-551396, 553834, 584726 \\ Fax. 0341-553834 \\ e-mail : $\underline{\text { Helmyadami@gmail.com }}$ \\ HP : 08563501425
}

\begin{abstract}
Performance measurement and universities in Indonesia is still considered very limited in terms of looking at the concept of higher education as an integral entity in the process of education and operations activities. Using four of Balanced Scorecard perspectives (financial, internal business processes, learning and growth, and customer) in developing performance measurement tools for management accountants in addition to do with strategic mission could theoretically be developed in college. Four perspective is revealed in some technical measures that will be described in this paper although some integral untested empirically.

Keywords: Internalisasi, perspektif, kinerja, nirlaba
\end{abstract}

Pengukuran kinerja tradisional lebih menekankan pada aspek keuangan sehingga banyak mengabaikan fakta performance lain yang sebenarnya juga penting. Data-data akuntansi lebih bersifat historis dan akan menghadapi kendala saat berbenturan dengan aset non-qantifiable seperti SDM, good-will/badwill, apalagi saat manajer akan berperilaku kurang bijak dalam merespon ukuran kinerja yang berbasis jangka pendek. Respon atas pengukuran ROI menjadikan manajer cenderung untuk malas berinvestasi, karena manajer berusaha menaikkan kinerjanya dalam jangka pendek. Prespektif ini berbahaya dalam kerangka pemikiran strategis perusahaan, karena perilaku ini bisa berbahaya dalan jangka panjang, contohnya nilai perusahaan akan turun, kepuasan dan loyalitas pelanggan akan turun, atau kalah bersaing karena rendahnya motivasi inovasi.

Pengukuran kinerja dalam prespektif yang strategis memerlukan penggabungan dari berbagai elemen area pengukuran. Balance scorecard sebagai 
salah satu alat yang mengintegrasikan elemen keuangan dan non-keuangan strategis, dengan pengintegrasian pengukuran outcome dan driver kinerja outcome dalam kerangka hubungan sebab akibat (Kaplan \& Norton 1996). Model ini telah menjadi alat kontemporer, sehingga menjadi topik perbincangan menarik dalam rangka memperkenalkan ide pokok dan tujuan balance scorecard, mengevaluasi, menginvestigasi, dan mengklarifikasikan beberapa asumsi yang mendasarinya.

Pendidikan Tinggi di Indonesia berkembang pesat seiring dengan laju pertumbuhan ekonomi dan era kemudahan dalam hal pendirian perguruan tinggi. Tingkat persaingan yang semakin hebat menjadikan perguran tinggi harus mampu melihat dirinya dalam berbagai kondisi. Beberapa kelemahan yang dialami oleh perguruan tinggi negeri terbawa-bawa juga di perguruan tinggi swasta, semisal mengenai budaya pengawai negeri yang bekerja tidak berorientasi pada hasil, namun lebih melihat proses/volume kerjanya. Jika mereka bekerja keras dan mereka yakin telah bekerja sekuat tenaga, tapi tidak mengetahui apa hasil yang diperoleh dan bagaimana mengevaluasinya (Kaplan \& Norton 1996:158).

Pengembangan model pengukuran kinerja yang lebih modern diperlukan, mengingat pengukuran kinerja perguruan tinggi cenderung tidak jelas, meskipun ada akreditasi dari Badan Akreditasi Nasional (BAN). Sebenarnya revolusi manajemen telah dilakukan dengan munculnya paradigma baru perguruan tinggi melalui konsep tetrahedron yaitu evaluasi, kualitas, akuntabilitas, otonomi, dan akreditasi (Suhendro 1996). Keterikatan institusional mulai dikurangi sejak tahun akademik 1997/1998 dengan tata cara pengajuan anggaran yang oleh dirjen DIKTI didasarkan pada kriteria kinerjanya (performance based) artinya perguruan tinggi didorong untuk mengadakan perencanaan yang sangat terkait dengan evaluasi dirinya (Semiawan 1998:73).

Artikel ini membahas mengenai ide penggunaan alat balance scorecard (BSC) yang diambil 4 prespektifnya untuk diaplikasikan dalam membuat evaluasi dan pengukuran kinerja perguruan tinggi. Walaupun aplikasi awal BSC untuk sektor laba, peluang scorecard dipakai untuk memperbaiki manajemen pemerintah atau perusahaan nirlaba bahkan lebih besar (Kaplan \& Norton 1996:175). Diharapkan ide 
ini akan mampu menjadi alat bantu revolusi manajemen PTS menuju arah pengukuran kinerja kontemporer yang tidak ketinggalan dengan organisasi bisnis.

\section{Manajemen Organisasi Nirlaba \& Manajemen Perguruan Tinggi}

Perbedaan orientasi organisasi bisnis dan nirlaba menjadikan pola manajemen jauh berbeda. Manajemen organisasi bisnis diarahkan untuk pencapaian tujuan maksimaliasi profit perusahaan dalam rangkan memperkaya shareholders. Manajemen organisasi nirlaba lebih diarahkan menuju upaya memberikan jasa tanpa mengharap kembalian yang setara dengan apa yang diterimanya. Kriteria organisasi nirlaba menurut PSAK No. 45 sebagai berikut:

a. Sumber daya entitas yang berasal dari para penyumbang yang tidak mengharapkan pembayaran kembali atau manfaat ekonomi yang sebanding dengan jumlah sumber daya yang diberikan

b. Menghasilkan barang dan/atau jasa tanpa bertujuan memupuk laba, dan kalau suatu entitas menghasilkan laba, maka jumlahnya tidak pernah dibagikan kepada para pendiri atau pemilik entitas tersebut

c. Tidak ada kepemilikan seperti lazimnya pada organisasi bisnis, dalam arti bahwa kepemilikan dalam organisasi nirlaba tidak dapat dijual, atau ditebus kembali, atau kepemilikan tersebut tidak mencerminkan proporsi pembagian sumber daya entitas pada saat likuidasi atau pembubaran entitas (IAI 1999)

Perkembangan manajemen organisasi nirlaba dan evaluasi kinerjanya cenderung dibuat asal-asalan atau kadang tidak jelas. Beberapa yayasan membuat laporan kinerja keuangan hanya untuk memenuhi tuntutan akuntabilitas penyumbangnya, dan bukan untuk perkembangan lembaganya sendiri.

Manajemen perguruan tinggi swasta kadang hanya membuat analisis kinerja keuangan berbasis laporan anggaran dan realisasi anggaran, serta beberapa evaluasi diri non-keuangan untuk keperluan akreditasi. Hal ini menjadikan evaluasi yang bersifat formal tidak berkembang, seolah manajemen pelaporan kinerja perguruan tinggi menganut azas kesederhanaan dalam pelaporan seperti organisasi nirlaba lainnya. 
Instruksi DIKNAS untuk memformalkan visi dan misi strategis dan perencanaannnya sebenarnya telah dipenuhi oleh pihak manajemen. Namun apakah visi dan misi tersebut sudah cocok sesuai dengan kriteria performanya, dan apakah strategi yang di buat bisa diaktualisasikan dalam tindakan. Harus kita ingat bahwa lembaga perguruan tinggi memegang amanah mulia dalam Tri Dharma Perguruan Tinggi (pendidikan dan pengajaran, pengabdian masyarakat, dan penelitian). Aktualisasi nilai tersebut perlu dilakukan dalam kerangka perencanaan formal dan bisa dievaluasi secara jelas. Perguruan tinggi mempunyai misi yang luhur dalam upaya mencerdaskan kehidupan bangsa, oleh karenya ada beberapa upaya dan parameter yang bisa dipakai sebagai paradigma yaitu kualitas pendikan sebagai civitas akademika yang sesuai dengan Tridharma perguruan tinggi, otonomi berarti kebebasan dan kemandirian untuk berkembang, akuntabilitas adalah pertanggungjawaban sebagai entitas pendidikan dalam memenuhi misi perguruan tinggi, evaluasi diri terkait dengan kemampuan perguruan tinggi untuk memahami dirinya dalam kondisi yang bagaimana, dan akreditasi merupakan penilaian oleh pihak independen/badan akreditasi bertaraf nasional tentang penyelenggaraan dan kinerja perguruan tinggi.

\section{Balance Scorecard (BSC): Konsep dan Strategi}

Balance scorecard didasarkan pada konsep strategi yang dikembangkan oleh Porter (Kaplan and Norton 1996:37). Porter beranggapan bahwa esensi dalam merumuskan strategi bersaing terletakpada hubungan perusahaan dengan pertarungan kompetitif pada industri dimana ia berada.

Scorecard sendiri menafsirkan strategis bisnis dalam 4 prespektif yaitu :

1. Keuangan-mengeidentifikasikan apa yang diharapkan oleh para pemegang saham

2. Pelanggan - mengidentifikasi apa yang diharapkan dan diperoleh pelanggan

3. Proses bisnis internal-mendeskripsikan proses bisnis pada perusahaan dalam rangka memuaskan pemegang saham dan pelanggan

4. Pembelajaran dan pertumbuhan-terkait dengan perubahan dan perbaikan yang diwujudkan dalam hal yang nyata. 
Hal tersebut terkait dalam rantai kausal, sehingga dalam presektif strategis, tujuan non-keuangan strategis harus terkait dengan keseimbangan dalam kerangka non-finansial dan finansial. Scorecard seharusnya berisi mengenai pengukuran outcome dan driver kinerja dari outcome tersebut dalam kerangka hubungan sebab akibat (Kaplan \& Norton 1996b:4). Rantai kausal yang dimaksud adalah: pengukuran pembelajaran dan pertumbuhan---pengukuran dalam proses bisnis internal---pengukuran dalam prespektif pelanggan---pengukuran dalam aspek keuangan.

Berikut ini penjelasan singkat dari 4 prespektif yang nantinya akan dicoba diadopsi dalam kerangka manajemen perguruan tinggi:

1. Prespektif finansial: kinerja keuangan akan berbasis pada upaya memberikan dampak laba maksimal bagi shareholders. Ini akan terkait dengan ukuran profitabilitas semisal laba operasi, return on capaital emplyed (ROCE), atau economic value added (EVA)

2. Prespektif bisnis internal: untuk mencapai kepuasan konsumen dan memberikan kontribusi laba pada shareholders, proses bisnis harus benarbenar dilakukan dengan efisien dan efektif, misalnya berbasis analisis rantai nilai, tingkar inovasi produk, proses operasi, ataupun delivery-nya.

3. Pembelajaran dan pertumbuhan: mengidentifikasi infrastruktur yang harus dibangun untuk menciptakan pertumbuhan dan peningkatan kinerja jangka panjang. Sumber utama pembelajaran dan pertumbuhan adalah manusia, sistem, dan prosedur perusahaan.

4. Prespektif pelanggan: indentifikasi pelanggan dan segmen pasar tempat suatu bisnis itu bersaing. Ukurannya biasanya terdiri dari: kepuasan pelanggan, retensi pelanggan, akuisisi pelanggan, profitabilitas penggan, dan pangsa pasar segmen sasaran.

Paradigma integralistik (memandang sesuatu sebagai satu kesatuan utuh) menjadikan BSC sangat cocok dengan adanya upaya untuk menginternalisasi proses Total Quality Management (TQM) dalam aspek manajemen entitas. Tulisan Purnama (2002) mencoba mengidentifikasi praktek TQM di perguruan tinggi di samping 
kendala-kendala penerapannya. Primiana (2002) mencoba menganalisis sejauhmana penerapan program kualitas di perguruan tinggi fakultas " $X$ " ditinjau dari aspek manusia, metode pengajaran, materi, dan fasilitas. Hasilnya risetnya menunjukkan perlunya penggunaan QFD (Quality Flow Diagram) dengan alat bantu TQM. Semiawan (1998:68) mensyaratkan perlunya TQM melalui (1)stimulasi dan koherensi proses belajar mengajar (2)analisis kebutuhan peserta didik.

Beberapa riset dan pemikiran tentang manajemen perguruan tinggi di atas menurut hemat penulis perlu ditindaklanjuti dengan pengembangan pengukuran kinerja integralistik melalui internalisasi 4 (empat) prespektif BSC. Kecenderungan di organisasi bisnis untuk mengukur kinerja hanya berbasis keuangan, akan sulit terjadi pada organisasi nirlaba seperti perguruan tinggi. Modifikasi teknik pengukuran kinerja tradisional di perguruan tinggi hanya bisa diterima dengan menggunakan prespektif yang integral, mengingat perguruan tinggi menyangkut kepentingan sosial masyarakat banyak, dan bukan untuk memperkaya pemiliknya.

\section{Visi dan Misi Strategi Perguruan Tinggi dan 4 Prespektif Balance Scorecard: Bagaimana Kesesuainnya?}

Pendidikan sebenarnya tergolong dalam kategori industri jasa yang bersifat nirlaba. Purwanto (2000) mencetuskan bahwa setidaknya perguruan tinggi yang profesional sudah mengarah pada suatu industri jasa yang berpelanggan dalam tingkatan eksternal dan internal. Tingkat Eksternal pada level primer adalah mahasiswa, sekunder adalah orang tua mahasiswa dan shareholder, dan tersier adalah pemakai tenaga lulusan perguruan tinggi. Tingkat Internal adalah dosen dan tenaga administrasi. Konsep nirlaba dalam bukan berarti menafikkan persaingan dan pemasaran (Ridiwiyanto \& Dharmmesta 2001).

Misi mulia pendidikan tinggi tercakup dalam Tri Dharma Perguruan Tinggi yang merupakan bagian dari upaya negara untuk mencerdaskan kehidupan bangsa.

Keberadaan perguruan tinggi sebagai suatu bagian dalam sistem pendidikan nasional menurut PP No. 60/1999 pasal 2 bertujuan untuk : 
1. Menyiapkan peserta didik menjadi anggota masyarakat yang memiliki kemampuan akademik dan perofesional yang dapat menerapkan, mengembangkan, dan memperkaya khasanah ilmu pengetahuan dan kesenian

2. Mengembangkan dan menyebarluaskan ilmu pengetahuan, teknologi, dan kesenian serta mengupayakan penggunaannya untuk meningkatkan taraf kehidupan masyarakat dan memperkaya budaya.

Misi dan tujuan di atas tergolong sangat normatif dan masih harus dijabarkan dalam aspek teknis. Namun hal tersebut bisa saja dianggap sebagai acuan inti manajemen perguruan tinggi. Saat menganalisis tetrahedron paradigma baru perguruan tinggi, sebenarnya sudah sangat jelas aspek Tri Dharma Perguruan Tinggi divisikan dalam sebuah paradima kualitas, otonomi, akuntabilitas, evaluasi diri, dan akreditasi. Oleh karena itu, modifikasi visi dan kecocokan pada BSC akan terlihat pada gambar analisis berikut ini:

Berikut ini disajikan tabel analisis konseptual mengenai identifikasi definisi 4 prespektif dalam konsep kombinasi paradigma baru perguruan tinggi (tabel 1) :

\begin{tabular}{|l|l|l|}
\hline \multicolumn{1}{|c|}{ BSC } & Paradigma Baru PT & \multicolumn{1}{c|}{ Definisi } \\
\hline Finansial & Akuntabilitas & $\begin{array}{l}\text { Pertanggujawaban, di samping bagaimana } \\
\text { PT melaporkan tanggungjawabnya secara } \\
\text { normatif, secara finansial PT juga membuat } \\
\text { laporan keuangan kepada para shareholders }\end{array}$ \\
\hline Proses Bisnis & Otonomi dan & $\begin{array}{l}\text { PT dituntut mandiri menyelenggarakan } \\
\text { proses aktivitasnya secara efisien dan } \\
\text { efektif. Kualitas proses belajar mengajar } \\
\text { harus diibaratkan sebagai suatu layout } \\
\text { produksi input (mahasiswa) menghasilkan } \\
\text { output yang handal }\end{array}$ \\
\hline Pembelajaran & Evaluasi diri & $\begin{array}{l}\text { PT menyadari akan posisinya. SDM (Dosen } \\
\text { \& Karyawan), sistem, dan prosedur } \\
\text { kebijakan harus dievalusi terus dan } \\
\text { dikembangkan seiring dengan pergeseran }\end{array}$ \\
\hline
\end{tabular}




\begin{tabular}{|l|l|l|} 
& & zaman (profesionalisme kelembagaan) \\
\hline Pelanggan & Akreditasi & Penilaian oleh pihak independen (BAN-PT) \\
& & yang berarti juga menilai tingkat \\
& & kompetensi PT dan respon pasar \\
& & terhadapnya. \\
\hline
\end{tabular}

Dari prespektif di atas bisa diturunkan dalam parameter ukur yang lebih spesifik, yaitu menurunkan dalam beberapa kajian teknis yang terjabar pada sesi selanjutnya.

\section{Rekonstruksi Teknik Pengukuran Kinerja: Aplikasi pada Perguruan Tinggi}

Cahyono (2000) mencoba memaparkan sejauhmana pengukuran kinerja BSC dipraktekkan pada organisasi sektor publik. Meskipun artikel tersebut cenderung sangat konseptual (kurang pragmatis) dalam arti bahwa beberapa prespektif BSC tidak dijabarkan dalam konteks organisasi sektor publik, namun tulisan ini mendukung ide Kaplan \& Norton (1996) dalam penggunaan BSC untuk organisasi non-profit. Nurkholis (2001) mencoba mengaplikasikan BSC untuk membuat perencanaan strategis di organisasi pemerintahan. Pendekatan yang dipakai adalah menurunkan misi dan visi strategis pemerintah dalam aplikasi 4 prespektif BSC. Tahun 1993 di Amerika, wakil presiden Al Gore mendorong diterbitkannya National Performance Review (NPR) yang kemudian dilaksanakan dengan gugus tugas Performance Measurement Action Team (PMAT). Hasilnya adalah mereka merekomendasikan BSC namun menambah satu prespektif--pemberdayaan pekerja (artinya BSC telah dimodifikasi menjadi 5 prespektif) yang menekankan peran pentingnya pekerja federal dalam memaksimalkan kepuasan pelanggan (Kaplan \& Norton 1996:158).

Adapun untuk aplikasi pada perguruan tinggi, penulis mencoba untuk tidak menambah 1 prespektif seperti yang dilakukan PMAT, namun mencoba mengaitkan ukuran-ukuran kinerjanya dalam rerangka sebagai berikut:

\section{Prespektif Finansial}

Ukuran finansial yang dipakai bukanlah laba, melainkan menurut Jones \& Pendlebury (1996) menggunakan 3 konsep fundamental yaitu economy, 
efficiency, dan effectivity. Jordan (1995:119) memformulasikan manajemen keuangan perguruan tinggi manajemen bantuan, investasi, uang tunai, anggaran, pembukuan (akuntansi), dan biaya-biaya. Selain itu output yang dipakai adalah laporan keuangan, artinya perguruan tinggi harus membuat laporan keuangan. Penelitian Adam (2002) berusaha merekonstruksi model pelaporan keuangan perguruan tinggi swasta berdasarkan PSAK No. 45 yang terdiri dari Neraca, Laporan Aktivitas, Laporan Arus Kas, dan beberapa laporan pendukung seperti Laporan Anggaran dan Realisasi, dan Laporan Beban Aktivitas Utama.

Herzlinger \& Nitterhouse (1994:552) memformulasikan indikator keuangan perguruan tinggi dalam formula sebagai berikut:

Balance Sheet

- $\quad$ Current Ratio

- $\quad$ Quick Ratio

- $\quad$ Assets by fund as a percentage of total assets

- Debt to total capital ratio

- $\quad$ Amount of unrestricted current and quasi endowment funds

- Amount of receivables and receivable turnover

- $\quad$ Reliance on interfund borrowing

Operating Statement

- $\quad$ Current funds expenditures to revenue

- Educational expenditures to eductional revenue

- $\quad$ Current fund gifts, grants, dan and contracts as percentage of revenue

- $\quad$ Educational and general to total current fund expenditures

- $\quad$ Student services to total current fund expenditures

- $\quad$ Student aid expenditures as a percentage of tuition and fees

- Current funds revenue to plant assets

- $\quad$ Fixed operating costs to revenue

Henke (1992:581) sendiri membagi kategori pengukuran kinerja keuangan dalam tiga prespektif yaitu 
- $\quad$ an effective set of budgetary procedures

- $\quad$ procedures for measuring input-output relationship

- $\quad$ financial performance reporting developed along authority-responsibility lines including cost allocations procedures that will facilitate appropriate pricing of services to users

\section{Prespektif Aktivitas Internal}

Acuannya adalah proses belajar mengajar dalam kerangka operating measurement. Beberapa indikator yang dipakai oleh Strange dan Banning (1998:68) mulai dari number of research grants, manuscripts published, full time equivalent (FTE) faculty, books read, student credit hours, dan public and professionals services. Herzlinger \& Nitterhouse (1994:555) menambahkan ukuran-ukuran yang lebih rinci sebagai berikut:

\begin{tabular}{|c|c|}
\hline $\begin{array}{l}\text { Students } \\
\text { Full time-equivalent enrollment } \\
\text { First-year application } \\
\text { Acceptance as a percent applications } \\
\text { Matriculants as a percent of } \\
\text { acceptances }\end{array}$ & $\begin{array}{l}\text { Tuition and Financial Aid } \\
\text { Tuition and fees per full-time student } \\
\text { Financial aid per full-time-equivalent } \\
\text { student } \\
\text { Institutionally funded financial aid as a } \\
\text { percent of total financial aid } \\
\text { Percent of students with college-work } \\
\text { study jobs }\end{array}$ \\
\hline $\begin{array}{l}\text { Faculty Admisnitration } \\
\text { Full-time-equivalent faculty } \\
\text { Full-time-equivalent adminitrators } \\
\text { Percent of faculty who are tenure } \\
\text { Percent of faculty } 60 \text { years or olders } \\
\text { Percent of faculty who are part-time }\end{array}$ & $\begin{array}{l}\text { Instruction } \\
\text { Number of degree program } \\
\text { Instructional expenditures as percent of } \\
\text { total expenditures } \\
\text { Instructional expenditures per full time } \\
\text { equivalent students }\end{array}$ \\
\hline $\begin{array}{l}\text { Research } \\
\text { Revenue for sponsored research } \\
\text { Institutionally funded research as a } \\
\text { percent of total research expenditures } \\
\text { Externally funded research as a percent } \\
\text { of total research expenditures }\end{array}$ & $\begin{array}{l}\text { Students Support } \\
\text { Full-time-equivalent students staff per } \\
\text { full time-equivalent students }\end{array}$ \\
\hline
\end{tabular}

Di Amerika banyak penelitian yang sebenarnya mencoba mengevaluasi produktivitas dosen melalui jumlah penerbitan dan jurnal, dan kepemilikan jurnal dari tiap universitas. Hasselback \& Reinstein (1995) mencoba menelusuri produktifitas dosen akuntansi di 716 perguruan tinggi 
di Amerika sesuai dengan data accounting faculty directory. Hasilnya bisa menjadi pembanding produktivitas antar entitas sejenis karena di situ diungkapkan juga ranking universitas paling produktif dalam riset akuntansi yaitu University of Albama.

\section{Perspektif Pembelajaran dan Pertumbuhan}

Perspektif ini sebenarnya berupaya bagaimana perguruan tinggi memahami kondisi dirinya sehingga membuat suatu rencana/program jangka panjang dalam rangka perbaikan berkelanjutan (continous improvement). Keterlibatan berbagai pihak, termasuk staf akademik akan menciptakan institutional commitment guna menumbuhkan kesadaran diri (untuk tumbuh dan berkembang) (Semiawan 1998:74). Usaha yang dilakukan oleh perguruan tinggi adalah :

a. Mendorong/memfasilitasi terciptanya budaya riset yang tinggi (karena jumlah publikasi di Indonesia masih rendah) baik itu untuk dosen maupun mahasiswa

b. Mendorong/memfasilitasi program belajar ke jenjang lebih tinggi untuk para dosen guna peningkatan kualitas proses belajar mengajar

c. Menciptakan sistem pendidikan (kurikulum) maupun penunjang yang disesuaikan dengan kemauan perkembangan pasar (proses dinamis)

Faktor SDM sangat ditekankan dalam proses pembelajaran dan pertumbuhan perguruan tinggi. Tenaga akademik sebagai human capital sebenarnya merupakan kunci keberhasilan perguruan tinggi. Upaya menyekolahkan dosen sebenarnya merupakan investasi yang diarahkan untuk menuju perbaikan intelectual capital. Upaya yang dilakukan adalah dengan meningkatkan kompetensi dengan cara buy (membeli), build (melakukan investasi untuk menjadikan karyawan lebih baik), borrow (meminjam atau mencari konsultan dari pihak luar), bounce (mengeluarkan karyawan yang gagal karena bisa merugikan) dan bind (mengikat karyawan agar sesuai dengan tujuan perusahaan atau menahan untuk tidak cepat keluar) (Sugeng 2000).

4. Prespektif Pelanggan 
Kunci utama keberhasilan management of higher eduction adalah orientasi klien (Semiawan 1998:69; Risdiwiyanto \& Dharmmesta 2001). Riset pasar perguruan tinggi bisa dilakukan tidak hanya saat akan menerbitkan produk (jurusan baru) tapi sebenarnya juga merupakan pengukuran kinerja entitas saat berjalan. Kerangka akreditasi perguruan tinggi sebenarnya bisa saja dipakai sebagai penilai pesaing atau sebagai alat pemetaan pasar. Kriteria akreditasi sudah cukup jelas misalnya mengenai kualitas lulusan, jumlah rasio dosen dan mahasiswa, gelar/kepangkatan/jabatan akademis, jumlah terbitan, jumlah riset, masalah input perguruan tinggi, serta sarana dan prasarana misalnya laboratorium, komputer, fasilitas penunjang, dan unsur administrasi. Parameter ini bisa dipakai dalam mengidentifikasi pasar, sebuah perguruan tinggi akan berada di posisi mana. Riset pasar yang benar-benar nyata dilakukan oleh Risdiwiyanto \& Dharmmesta (2001) dengan populasi responden seluruh siswa SMA kelas tiga di Yogyakarta dan Jawa Tengah.

Dengan berbasis riset pasar, sebenarnya perguruan tinggi akan mengetahui dia berada di mana dan saat melihat preferensi konsumen (meski kadang dilematis) perguruan tinggi bisa menyesuaikan kebijakan atau strateginya untuk bisa menang di pasaran. Harus berhati-hati bahwa semua itu tidak boleh menyimpang dari misi strategis dalam Tri Dharma Perguruan Tinggi.

\section{Kendala Teknis dan Aplikasi}

Aplikasi ide internalisasi BSC tentunya bukan suatu hal yang mudah. Beberapa perguruan tinggi masih sangat terikat platform untuk memenuhi standar kinerja berbasis kemauan organisasi di atasnya (semisal PTN dengan basis ketentuan DIKTI). Khususnya untuk pengukuran kinerja keuangan, masih sedikit PTS (tidak PTN karena PTN tidak memakai PSAK No. 45 dalam pelaporan keuangannya) yang menggunakan PSAK No. 45 atau menggunakan double entry book-keeping dalam proses akuntansinya. Ketentuan dari DIKTI kadang kurang mendukung, meskipun 
DIKTI selalu mengharuskan PT untuk membuat perencanaan strategis, disamping evaluasi DIKTI melalui proses akreditasi nasional.

\section{KESIMPULAN}

Balance scorecard merupakan alat sistematis bukan hanya sebagai pengukur kinerja, tapi juga sebagai alat kontrol strategis. Balance scorecard mengarah pada perluasan prespektif bukan hanya pada aspek finansial saja yang cenderung membawa perilaku negatif manajer, tapi ke segenap aspek internal maupun eksternal perusahaan.

Ide BSC untuk dijadikan alat ukur kinerja sangat mungkin untuk dipraktekkan di manajemen perguruan tinggi. 4 prespektif yang diajukan penulis tidak terlalu mengalami banyak modifikasi, hanya proses bisnis internal digantikan dengan proses aktivitas (operasi) internal. Penggunaan BSC secara teoritis bisa mendukung program pemberdayaan perguruan tinggi dalam rangka memenuhi tri dharma perguruan tinggi, dengan kombinasinya melalui konsep tetrahedron paradigma baru perguruan tinggi.

Tulisan ini mengandung keterbatasan, karena masih sangat konseptual dan hanya merupakan ide yang prakteknya masih belum terbukti secara empiris. Ada baiknya penelitian selanjutnya lebih mengarahkan pada pengukuran kinerja dari masing-masing 4 prespektif, yang kemudian dikombinasikan dalam konsep Balance Scorecard. 


\section{DAFTAR PUSTAKA}

Adam, Helmy, 2002, Kemungkinan Penerapan PSAK No. 45 tentang Pelaporan Keuangan Organisasi Nirlaba sebagai Penunjang Akuntabilitas Keuangan Perguruan Tinggi Swasta (Studi Kasus pada Universitas Malang), Fakutas Ekonomi Unibraw, Malang.

Cahyono, Dwi, 2000, Pengukuran Kinerja Balance Scorecard untuk Organisasi Sektor Publik, Jurnal Bisnis dan Akuntansi Vol. 2 No, 3

Dikti, 1999, Peraturan Pemerintah Republik Indonesia No. 60 Tahun 1999 tentang Pendidikan Tinggi \& Peraturan Pemerintah Republik Indonesia No. 61 Tahun 1999 tentang Penetapan Perguruan Tinggi sebagai Badan Hukum.

Freeman, Robert J., Craig D. Shoulders, 1999, Governmental and Nonprofit Accounting (Theory and Practice), $6^{\text {th }}$ edition, Prentice Hall Inc., New Jersey USA.

Hasselback, James R., Alan Reistein, 1995, A Proposal for Measuring Scholarly Productivity of Accounting Faculty, Issues in Accounting Education Vol. 10 No. 2

Henke, Emerson E., 1992, Introduction to Nonprofit Organization Accounting, Fourth Edition, South Western Publishing Co., Cincinati.

Hezlinger, Regina E., Denise Nitterhouse, 1994, Financial Accounting and Managerial Control for Non-Profit Organizations, South-Western Publishing, Cincinanti, Ohio.

IAI, 1999, Standar Akuntansi Keuangan, Salemba Empat, Jakarta.

Jones, Rowan, Maurice Pendlebury, 1992, Public Sector Accounting, Pitman Publishing, London.

Jordan, Thomas E., 1995, Pengukuran \& Evaluasi di Perguruan Tinggi (terjemahan), Penerbit IKIP Semarang Press, Semarang.

Kaplan, Robert M., David Norton, 1996, Balance Scorecard (Menerapkan Strategi Menjadi Aksi), Erlangga, Jakarta.

Nurkholis, 2001, Perencanaan Strategik Organisasi Pemerintahan dengan Pendekatan Balance Scorecard, Lintasan Ekonomi Vol. XVIII No. 1

Primianan, Ina, 2002, Penerapan Kualitas di perguruan Tinggi (Penggunaan diagram Sebab Akibat, Diagram Pareto dan QFD), Jurnal Bisnis dan Manajemen Vol. 1 No. 1

Purnama, Nursyabani, 2002, Analisis Kendala Potensial Penerapan Total Quality Service pada Perguruan Tinggi , Jurnal Ekonomi dan Bisnis, Vol. 17 no. 2 
Purwanto, Era, 2000, Sistem Pendidikan Profesional dan Perkembangannya di Indonesia (disampaikan dalam Seminar Nasional Pengembangan Program Diploma IV 17 Juni 2000), Hotel Santika, Yogyakarta.

Risdiwiyanto, Andriya, Basu Swasta Dharmmesta, 2001, Pengembangan Konsep Jasa Perguruan Tinggi Berbasis Keinginan Konsumen Potensial, Jurnal Eknomi dan Bisnis Indonesia, Vol 16, No. 4.

Sabeni, Arifin, Imam Ghozali, 1997, Pokok-Pokok Akuntansi Pemerintahan, Edisi Ke-4,

Semiawan, Cony R., 1998, Pendidikan Tinggi Peningkatan Kemampuan Manusia Sepanjang Hayat Seoptimal Mungkin, Direktorat Jenderal Pendidikan Tinggi, Jakarta

Strange, C. Carney, James Banning, 1998, Educating by Design, Jossey Bass-A Willey Company, San Francisco

Sugeng, Imam, 2000, Mengukur dan Mengelola Intelectual Capital, Jurnal Ekonomi dan Bisnis Indonesia, Vol. 2 